\title{
Physical Exercises for the Elderly with Diabetes Mellitus Type 2
}

\author{
Suci Tuty Putri*, Upik Rahmi, Sri Sumartini, Lisna Anisa Fitriana, Sehabudin Salasa \\ Program Study of Nursing, Faculty of Sport and Health Education \\ Universitas Pendidikan Indonesia \\ Bandung, Indonesia \\ *suci.putri@upi.edu, upikrahmi@upi.edu, srisumartini@upi.edu, lisna@upi.edu,kang_sehab@upi.edu
}

\begin{abstract}
Diabetes mellitus type 2 is a common problem that occurs in various developing countries and has increased significantly. The increasing number of elderly also causes an increase in the incidence of this disease due to the decreases in muscle function and insulin sensitivity in elderlies which affect glucose levels in the blood. Physical exercise is one of the pillars in the management of diabetes mellitus type 2 . This article will describe various physical exercises in the elderly with diabetes mellitus type 2. The source of data used google scholar, springer exemplar, and science direct. 7 articles that meet the criteria were then analyzed with thematic analysis. The principle of physical exercise in the elderly with diabetes mellitus is by paying attention to the type of exercise, intensity, duration, and frequency of exercise. Furthermore, it is expected that physical exercise in the elderly can be developed with various models as a part of the development of diabetes mellitus management.
\end{abstract}

Keywords: diabetes mellitus type 2, elderly, exercises, physical training

\section{INTRODUCTION}

Diabetes mellitus (DM) is a non-infectious disease whose prevalence continues to increase every year. Data from the World Health Organization (WHO) in 2015 shows that diabetes is the seventh leading cause of death in Indonesia in adult diseases [1]. The results of a study from the International Diabetes Federation in 2017 revealed that there were 425 million people with Diabetes Mellitus worldwide. Indonesia is ranked seventh in the country with the most diabetics, namely 7.6 million people [2]. Type 2 diabetes is the most common type of diabetes, which is about $90 \%$ of all people with diabetes and often occurs at the age of 40 years and above [3]. The prevalence of this disease continues to increase mainly due to changes in lifestyle, an increase in the number of calories eaten, a lack of physical exercise and an increasing number of elderly population [4]. Physical activity is recognized as an integral part of primary preventive measures for people at risk of DM and secondary prevention for patients with DM.

Physical activity in which physical exercise is very important in maintaining the physical health of individuals. Physical exercise is associated with obesity and is known to be a third risk factor for non-infectious diseases such as cardiovascular disease, DM type 2, cancer 2. Physical exercise in people with DM has a very important role in controlling blood glucose levels. During physical exercise, the whole body will increase oxygen intake up to 20 times and increase the work of the muscles of the body. This triggers an increase in the breakdown of glycogen, triglycerides and free fatty acids (FFAs) in muscles. Physical exercise in the elderly is healthrelated fitness that is heart-lung fitness and blood circulation as well as muscle strength and joint flexibility [5].

The elderly are the population group with the largest percentage of DM patients. The results of Riskesdas in 2013 showed the percentage of elderly with DM was 8.3\% [6]. Various research results also show an increased risk of DM with age [6]. Increasing age in individuals will cause a decrease in strength, muscle mass, and insulin sensitivity, but this should be prevented by regular physical exercise. The type of physical exercise recommended for DM patients is aerobic exercise. A study by Abe R \& Fujinuma $\mathrm{H}$ showed that older people did more regular physical exercise than middle adulthood, but the effect on lowering blood glucose levels was lower than in middle adulthood. This needs to be studied in more depth regarding proper physical exercise for the elderly. This article aims to find out the types of physical exercise and its effects on T2DM.

\section{METHOD}

The design employed was a systematic review. The data was obtained from Google Scholar, Springer Link, Science Direct, Scopus from 2015-2019. The keywords involve "Physical Activity" and Diabetes Mellitus" and "Eldery". Reviews in the articles follow the research criteria. The inclusion criteria as follows: (1) Articles published articles are written in Indonesian and English. (2) The article focuses on physical activity interventions in elderly patients with T2DM. (3) Article of research on open access and full text. Articles searching and summarizing the relevant articles. The consideration of relevance based on the clarity of resources and correlation with the topic. The analysis of results using descriptive thematic analysis.

\section{RESULT}

From the search results found 1,530 articles, Google Scholar, 227 articles springer links, 11,700 articles on science direct. The article was selected based on the specified criteria. Researchers found 7 articles that match. Researchers analyzed each of these articles. Details of articles are presented in table 1. 
TABLE I. THE SUMMARY OF THE ARTICLE ON EXERCISE TRAINING OF ELDERLY WITH DIABETES MELLITUS

\begin{tabular}{|c|c|c|c|c|c|c|}
\hline No & Authors & Title & Year & Design & Method & Findings \\
\hline 1 & $\begin{array}{lr}\text { Gian } & \text { Pietro } \\
\text { Emerenziani, } & \text { Maria } \\
\text { Chiara } & \text { Gallotta, } \\
\text { MarcoMeucci, } & \text { Luigi } \\
\text { Di Luigi, } & \\
\text { Silvia } & \text { Migliaccio, } \\
\text { Lorenzo r raria } \\
\text { Donini, Felice Strollo, } \\
\text { and Laura Guidetti [7] }\end{array}$ & $\begin{array}{l}\text { Effects of Aerobic } \\
\text { Exercise Based upon } \\
\text { Heart Rate at Aerobic } \\
\text { Threshold in Obese } \\
\text { Elderly Subjects with } \\
\text { Type 2 Diabetes }\end{array}$ & 2015 & $\begin{array}{l}\text { Experime } \\
\text { ntal } \\
\text { design } \\
\text { with } \\
\text { randomiz } \\
\text { e } \\
\text { sampling }\end{array}$ & $\begin{array}{l}30 \text { elderly (age } 66.8+6.3 \text { y. } 15 \text { subjects } \\
\text { intervention and } 15 \text { subjects control } \\
\text { Test were performesd at baseline and after } 3 \\
\text { months in both group }\end{array}$ & $\begin{array}{l}\text { After training, patinets enrolled in Intervention had } \\
\text { significantly hiher }(\mathrm{P}<0.001) \mathrm{VO} 2 \text { peak, MET peak, } \\
\text { WR peak and WR aet Tgd significantly lower } \\
(\mathrm{p}<0.005) \text { weight, BMI, \%FM and waist } \\
\text { circumference than before intervention period. But no } \\
\text { significant differences were found for all the between } \\
\text { pre and posttraining and between groups }\end{array}$ \\
\hline 2 & $\begin{array}{lr}\text { Joan Kelly, } & \text { Katrina } \\
\text { Edney, Chris } & \text { Moran, } \\
\text { Velandai } & \text { Srikanth, } \\
\text { and } & \text { Michele } \\
\text { Callisaya[8] } & \\
\end{array}$ & $\begin{array}{l}\text { Gender Differences in } \\
\text { Physical Activity Levels } \\
\text { of Older People } \\
\text { With Type } 2 \text { Diabetes } \\
\text { Mellitus }\end{array}$ & 2016 & $\begin{array}{l}\text { Cohort } \\
\text { Study }\end{array}$ & $\begin{array}{l}2 \text { groups obtained } 293 \text { participants with } \\
\text { T2DM and } 336 \text { without T2DM }\end{array}$ & $\begin{array}{l}\text { In women, T2DM wa associated with fewer mean } \\
\text { steps per day; not meeting Phisical Activity } \\
\text { guidelines. }\end{array}$ \\
\hline 3 & $\begin{array}{l}\text { Lucia Cugusi, PhD, } \\
\text { Christian Cadeddu, } \\
\text { MD, PhD, Silvio } \\
\text { Nocco, MD, PhD, } \\
\text { Fabio Orru, MD, } \\
\text { Stefano Bandino, } \\
\text { MD, Martino Deidda, } \\
\text { MD, Alessandra } \\
\text { Caria, MSc, Pier } \\
\text { Paolo Bassareo, MD, } \\
\text { PhD, Alessandra } \\
\text { Piras, MD, PhD, } \\
\text { Sergio Cabras, MD, } \\
\text { Giuseppe Mercuro, } \\
\text { MD[9] }\end{array}$ & $\begin{array}{l}\text { Effects of an Aquatic- } \\
\text { Based Exercise Program } \\
\text { to Improve } \\
\text { Cardiometabolic Profile, } \\
\text { Quality of Life, and } \\
\text { Physical Activity Levels } \\
\text { in Men With Type } 2 \\
\text { Diabetes Mellitus }\end{array}$ & 2015 & $\begin{array}{l}\text { Observati } \\
\text { onal } \\
\text { study, } \\
\text { communit } \\
\text { y pre-post } \\
\text { aquatic- } \\
\text { based } \\
\text { exercise } \\
\text { program, } \\
\text { primary } \\
\text { care inter } \\
\text { vention }\end{array}$ & $\begin{array}{l}\text { Eighteen men diagnosed with } 2 \mathrm{DM} \\
\text { Main Outcome Measurements: } \\
\text { Cardiometabolic profile, quality of life, and } \\
\text { physical activity levels were assessed before } \\
\text { and after } 12 \text { weeks of an aquatic-based } \\
\text { exercise program }\end{array}$ & $\begin{array}{l}\text { The results show a significant improvement of } \\
\text { cardiometabolic assessments (maximum oxygen } \\
\text { consumption } \\
24.1 \text { versus } 21.1 \mathrm{~mL} / \mathrm{kg} / \mathrm{min}, \mathrm{P}<.05 \text {; blood pressure: } \\
125.4 / 77 \text { versus } 130.7 / 82.5 \mathrm{~mm} \mathrm{Hg}, \mathrm{P}<.05 \text {; } \\
\text { fasting blood glucose: } 119.6 \text { versus } 132.5 \mathrm{mg} / \mathrm{dL}, \mathrm{P}< \\
.05 \text {; body mass index: } 29.9 \text { versus } 31.1 \mathrm{~kg} / \mathrm{m}^{2}, \mathrm{P}< \\
.005 \text {; low-density lipoprotein cholesterol: } 95.2 \text { versus } \\
104.9 \mathrm{mg} / \mathrm{dL}, \mathrm{P}<.05 \text {; and diastolic function: } \mathrm{E} / \mathrm{E}^{\prime} 9.1 \\
\text { versus } 10.1, \mathrm{P}<.005 \text { ) and an increase in quality of } \\
\text { life and physical activity and energy expenditure in } \\
\text { general physical activity (physical activity: } 3888.7 \\
\text { versus } 1239.5 \mathrm{kcal} / \mathrm{wk}, \mathrm{P}<.05 \text { ). }\end{array}$ \\
\hline 4 & $\begin{array}{lr}\text { Kishan } & \text { Bakrania, } \\
\text { Charlotte } & \text { L. } \\
\text { Edwardson, } & \text { Kamlesh } \\
\text { Khunti, } & \text { Joseph } \\
\text { Henson, } & \text { Emmanuel } \\
\text { Stamatakis, } & \text { Mark } \\
\text { Hamer, } & \text { Melanie J. } \\
\text { Davies, r } & \text { Thomas } \\
\text { Yates[10] } \\
\end{array}$ & $\begin{array}{l}\text { Associations } \\
\text { objectively measured } \\
\text { moderate-to-vigorous- } \\
\text { intensity physical } \\
\text { activity and sedentary } \\
\text { time with all-cause } \\
\text { mortality in a population } \\
\text { of adults at high risk of } \\
\text { type } 2 \text { diabetes mellitus }\end{array}$ & 2017 & $\begin{array}{l}\text { Experime } \\
\text { ntal }\end{array}$ & $\begin{array}{l}\text { At baseline, participants were randomised to } \\
\text { usual care or the three-hour Walking Away } \\
\text { structured education programme with } \\
\text { ongoing annual support Participants were } \\
\text { followed up at } 12,24 \text { and } 36 \text { months. Over } \\
\text { the } 36 \text { months, levels of physical activity or } \\
\text { sedentary behaviour between the two arms }\end{array}$ & $\begin{array}{l}\text { findings demonstrate that the risk of death was } \\
\text { reduced by } 5 \% \text { for every } 10 \% \text { increase in MVPA } \\
\text { time in adults at high risk of T2DM }\end{array}$ \\
\hline 5 & $\begin{array}{lr}\begin{array}{lr}\text { M. Mogharnasi, } \\
\text { TajiTabas, }\end{array} \\
\text { Tashakorizadeh, } & \text { S.H. } \\
\text { Nayebifar[11] } & \end{array}$ & $\begin{array}{l}\text { The Effects of } \\
\text { Resistance and } \\
\text { Endurance Training on } \\
\text { Levels of Nesfatin-1, } \\
\text { HSP70, Insulin } \\
\text { Resistance and Body } \\
\text { Composition in Women } \\
\text { with Type } 2 \text { Diabetes } \\
\text { Mellitus }\end{array}$ & 2019 & $\begin{array}{l}\text { experime } \\
\text { ntal }\end{array}$ & $\begin{array}{l}26 \text { women with type } 2 \text { diabetes were selected } \\
\text { using purposive sampling and were randomly } \\
\text { divided into three groups. } 10 \text { subjects } \\
\text { participated in the resistance training group } \\
\text { ( } 3 \text { sessions per week, exercising with } 30- \\
80 \% \text { of one repetition maximum ( }(1 \mathrm{RM}) \text { ), } \\
8 \text { subjects participated in the endurance } \\
\text { training group ( } 3 \text { sessions per week, } \\
\text { exercising with } 40-80 \% \text { of maximum heart } \\
\text { rate (HR max), for } 20-45 \text { minutes), and } \\
8 \text { subjects were placed in the control group } \\
\text { who did not engage in any physical exercise } \\
\text { during the study period. }\end{array}$ & $\begin{array}{l}\text { There was a significant increase in nesfatin- } 1 \text { levels } \\
\text { and a significant decrease inHSP70 levels of the } \\
\text { resistance training group, }(\mathrm{P}<0.05 \text { ), whereas no } \\
\text { significant changes were observed in nesfatin-1 and } \\
\text { HSP70 levels of the endurance training group (P > } \\
0.05 \text { ). Glucose levels, insulin resistance (HOMA1- } \\
\text { IR) and body composition indices (except for WHR) } \\
\text { significantly decreased in both training groups (P < } \\
0.05 \text { ). However, there were no significant changes in } \\
\text { insulin levels of the training groups ( } \mathrm{P}>0.05 \text { ). } \\
\text { Moreover, comparing the pre- and post-test levels of } \\
\text { glucose changes, a significant difference was } \\
\text { observed in the resistance and endurance training } \\
\text { groups but not in the control group ( } \mathrm{P}<0.05 \text { ). }\end{array}$ \\
\hline 6 & $\begin{array}{l}\text { Fernanda Maria } \\
\text { Martinsa, Aletéia de } \\
\text { Paula Souzaa, Paulo } \\
\text { Ricardo Prado Nunesa } \\
\text { Márcia Antoniazi } \\
\text { Micheline , Eddie } \\
\text { Fernando Candido } \\
\text { Murtac, Elisabete } \\
\text { Aparecida Mantovani } \\
\text { Rodrigues Resendec , } \\
\text { Erick Prado de } \\
\text { Oliveirad, Fábio Lera } \\
\text { Orsatti[12] }\end{array}$ & $\begin{array}{l}\text { High-intensity } \\
\text { bodyweight training is } \\
\text { comparable to combined } \\
\text { training in changes in } \\
\text { muscle mass, physical } \\
\text { performance, } \\
\text { inflammatory markers } \\
\text { and metabolic health in } \\
\text { postmenopausal women } \\
\text { at high risk for type } 2 \\
\text { diabetes mellitus: }\end{array}$ & 2018 & $\begin{array}{l}\text { A } \\
\text { randomiz } \\
\text { ed } \\
\text { controlled } \\
\text { clinical } \\
\text { trial }\end{array}$ & $\begin{array}{l}16 \text { PW at high risk of TDM } 2 \text { was randomly } \\
\text { allocated into } \\
\text { two groups: HIBWT ( } \mathrm{n}=8 \text { ) and COMT ( } \mathrm{n}=8 \text { ). } \\
\text { The HIBWT group performed a training } \\
\text { protocol (length time } \\
\sim 28 \text { min) consisting of ten sets of } 60 \mathrm{~s} \text { of } \\
\text { high-intensity exercise interspersed by a } \\
\text { recovery period of } 60 \mathrm{~s} \text { of low } \\
\text {-intensity exercise. The COMT group } \\
\text { performed a training protocol (length time } \\
\sim 60 \text { min) consisting of a } 30 \text { min } \\
\text { walk of the moderate-intensity following by } \\
\text { five resistance exercises. All training } \\
\text { sessions were performed in the } \\
\text { university gym facility three days a week (no } \\
\text { consecutive days) for } 12 \text { weeks. }\end{array}$ & $\begin{array}{l}\text { Both groups increased }(\mathrm{P}<0.05) \text { muscle mass index } \\
(\mathrm{MMI}), 6 \mathrm{MWT} \text {, and interleukin } 1 \text { receptor antagonist } \\
\text { and decreased fasting glucose, glycated hemoglobin, } \\
\text { Insulin, HOMA-IR, and monocyte chemoattractant } \\
\text { protein-1 (trend, } \mathrm{P}=0.056) \text {. HIBWT effects were } \\
\text { indistinguishable }(\mathrm{P}>0.05) \text { from the effects of } \\
\text { COMT. There } \\
\text { was a significant }(\mathrm{P}<0.05) \text { interaction of time by the } \\
\text { group in muscle strength, indicating that only the } \\
\text { COMT } \\
\text { increased muscle strength }\end{array}$ \\
\hline 7 & $\begin{array}{l}\text { L.C. Cruz, A.A. } \\
\text { Teixeira-Araujoa,, } \\
\text { K.T.P. Andrade, } \\
\text { T.C.O.G. Rocha, S.R. } \\
\text { Moreira[13] }\end{array}$ & $\begin{array}{l}\text { Low-intensity resistance } \\
\text { exercise attenuates the } \\
\text { relationship between } \\
\text { glucose and autonomic } \\
\text { nervous system } \\
\text { indicators during } 24 \\
\text { hours in women with } \\
\text { type } 2 \text { diabetes }\end{array}$ & 2018 & $\begin{array}{l}\text { randomiz } \\
\text { ed block } \\
\text { design }\end{array}$ & $\begin{array}{l}20 \text { postmenopausal women with T2D } \\
\text { between } 48 \text { and } 60 \text { years old took part in the } \\
\text { study. }\end{array}$ & $\begin{array}{l}\text { a single RE session attenuates the correlation between } \\
\text { glucose and RRi values. Besides, low-intensity RE } \\
\text { session provides the extinction of the correlation } \\
\text { between glucose and autonomic nervous system } \\
\text { indicators in postmenopausal women with T2D. }\end{array}$ \\
\hline
\end{tabular}




\section{A. Physical Exercises}

Physical exercise is often associated with the development of DMT2 complications. Elderly with DM if able to do regular exercise, especially strength training, the weight, and blood glucose levels can be controlled better.

Physical exercise is known to increase insulin sensitivity to receptors in muscles and tissues, besides that the risk of cardiovascular complications such as hyperlipidemia and hypertension can be reduced with regular and proper physical exercise $[4,14]$. Physical exercise in the elderly with DM has a risk, however physical exercise can trigger angina execration or ischemia in patients with cardiovascular disorders [4].

The presence of peripheral neuropathy causes the risk of injury to an increase in the elderly with DM. Symptoms of hypoglycemia can also occur in the elderly with oral medication. The American Diabetes Association recommends elderly people who want to do more than just walk to assess the risk of cardiovascular disease and other diseases [4].

The purpose of physical exercise for people with DM include (1)To get a good metabolism; (2) To reduce weight; (3) To increase physical capacity; (4) To improve the quality of life; (5) To improve cardiovascular function and dyslipidemia; (6) Improve sleep quality, improve digestive function $[1,15]$.

Specific analysis of appropriate physical exercise based on an evidence base needs to be carried out to obtain guidance on an appropriate and safe program. In table 1, we will present some of the results of research related to physical exercise in the elderly.

Type of exercise. Helping the elderly in choosing the right and comfortable physical exercise is important in the success of physical exercise activities. An appropriate physical training program must include strength, flexibility and balance training [15]. Physical activity in the elderly must pay attention to FITT (frequency, intensity, time, type). This type of physical exercise is also suggested to have a social aspect as well as an impact on elderly emotions. Exercises suitable for the elderly with T2DM include [16-18].

Aerobic Exercise. This includes rhythmic activities, repetition and continuous movement in large muscle groups for at least 10 minutes. These exercises tend to be safe for the elderly, for example walking, jogging, swimming, cycling and aerobic exercises [16,17].

For older people over the age of 65 , it is recommended to do sports that do not overload bones, and start from the low intensity and gradually increase in behavior based on tolerance to physical exercise [18].

Muscle-strengthening / endurance exercises. Exercises that use muscle strength to move or lift weights, endurance exercises are chosen for each muscle group [16]. Physical exercises for strengthening muscles are activities that strengthen and support the muscles and connective tissue. Exercises are designed so that the muscles are capable of strength to move or hold weights such as standing movements from a chair, held for several seconds repeatedly, training with elastic straps. Muscle-strengthening exercises done at least 2 days a week with rest between sessions [18].

Muscle-strengthening training for $2.5 \mathrm{x} / \mathrm{mgg}$ for $>8 \mathrm{mg}$ in adults has been shown to reduce HbA1C levels even though there is no significant change in body mass index [16].

Flexibility Exercises. Flexibility or stretching exercises aim to increase the range of motion of the muscles and help reduce the risk of injury. Flexibility exercises are designed to involve every major joint (hip, back, shoulder, knee, and neck). Flexibility training is recommended to be done in conjunction with aerobic and muscle-strengthening exercises, 2-3 x / week, examples of flexibility exercises are ROM and yoga. Balance training also needs to be done to prevent the elderly from falling, at least 3 days a week, this exercise is done in low intensity.

1) Exercise protocol: Standard protocol in physical exercise for people with DM includes 4 stages

- Stage 1: warming up for 5-10 minutes aerobic with lowintensity level

- Stage 2: Muscular stretching for 5-10 min

- Stage 3: core training

- Stage 4: cooling for 5-10 min which will help HR return to before training.

Physical training programs for the elderly are arranged in stages. For example, starting with a low intensity of $40-50 \%$ resting pulse for 10-20 min is increased according to the ability to adapt to each individual's training gradually.

Monitor blood sugar and hypoglycemic signs need to be considered during physical exercise. Effects of Physical Exercise on Metabolism. Physical exercise helps the absorption of the hormone insulin into cells to form energy. Muscles use glucose better than fat 4 . The mechanisms that occur in glucose control include improvements in insulin sensitivity and effects on Glucose Transporters (GLUT4), the muscle contracting simultaneously with the transfer of GLUT4 into the plasma membrane directly. During 5-10 minutes of exercise, glycogen becomes the main source of energy, with glycogen training in the muscles will be depleted and glucose will be replaced by glucose from the liver and the results of neogluconeogenesis. If the exercise continues for several hours this will contribute to reducing glucose and FFAs which are the main fuel [17]. The effect of exercise on insulin does not exceed 72 hours, so it is recommended no more than two days the distance between exercises. Moderate-intensity exercise for $30 \mathrm{~min} / \mathrm{hr}$ is the most ideal, but those who are unable to do it every day should be able to reach $150 \mathrm{~min} \mathrm{/} \mathrm{week} \mathrm{at} \mathrm{least} 3$ days / week $[16,17,19,20]$.

Marwick et al's research state that exercise stimulates metabolic improvement, influences HbA1c blood glucose and insulin sensitivity6. There is an improvement in the average $\mathrm{HbA} 1 \mathrm{c}$ value of $-0.38 \%$ to $-0.97 \%$ at practice [19].

\section{CONCLUSION}

The purpose of physical exercise for people with DM include (1)To get a good metabolism; (2) To reduce weight; (3) 
[10] K. Bakrania, C.L. Edwardson, K. Khunti, J. Henson, E. Stamatakis, M. Hamer, M.J. Davies, T. Yates, "Associations of objectively measured moderate-to-vigorous-intensity physical activity and sedentary time with all-cause mortality in a population of adults at high risk of type 2 diabetes mellitus," Preventive medicine reports, vol. 5, pp. 285-8, 2017.

[11] M. Mogharnasi, A. TajiTabas, M. Tashakorizadeh, S.H. Nayebifar, "The Effects of Resistance and Endurance Training on Levels of Nesfatin-1, HSP70, Insulin Resistance and Body Composition in Women with Type 2 Diabetes Mellitus. Science \& Sports,” vol. 34(1), pp. 15-23, 2019.

[12] F.M. Martins, A. de Paula Souza, P.R. Nunes, M.A. Michelin, E.F. Murta, E.A. Resende, E.P. de Oliveira, F.L. Orsatti, "High-intensity bodyweight training is comparable to combined training in changes in muscle mass, physical performance, inflammatory markers and metabolic health in postmenopausal women at high risk for type 2 diabetes mellitus: A randomized controlled clinical trial. Experimental gerontology," vol. 107, pp. 108-15, 2018.

[13] L.C. Cruz, "Low intensity resistance exercise attenuates the relationship between glucose and autonomic nervous system indicators during 24 hours in women with type 2 diabetes. Sci sports," 2017, retrieved from: https://doi.org/10.1016/j.scispo.2017.10.004.

[14] ADA, "Physical activity/exercise and diabetes," 2004, retrieved from: http://care.diabetesjournals.org/content/27/suppl_1/s58.full.pdf+html.

[15] M. Wallace, "Essential Gerontological Nursing" New York. Springer Publishing Company, 2008.

[16] N. Davila, "Physical activity in Puerto Rican adults with type 2 diabetes mellitus. Ph.D dissertation, The University of Arizona, United StatesArizona," from Dissertations \& Theses: Full text ( Publication No.AAT 3404197, March 26, 2011.

[17] M. Khan,'Exercise for the Management of Diabetes Mellitus: A Review of the Evidence," Journal Of Enam Medical College, vol. 3(2), pp. 99108, 2013, retrieved from: doi:10.3329/jemc.v3i2.16133.

[18] R. L. Ambardini, "Aktivitas Fisik Pada Lanjut Usia," retrieved from: http://staff.uny.ac.id/sites/default/files/132256204/Aktivitas\%20Fisik\%2 OLansia.pdf .

[19] T.H. Marwick, M.D. Horden, etc, "Exercise training for Type 2 Diabetes Mellitus, impact on cardiovascular risk. A scientific statement from the American Heart Association," 2009, retrieved from: http://circ.ahajournals.org/content/119/25/3244.full.pdf.

[20] D.Tessier, J. Menard, etc, "Effect of aerobic physical exercise in elderly with type 2 diabetes mellitus," Arch Geriatr, vol. 31, pp. 121-132, 2000. 